\title{
ECLETICA
}

www.scielo.br/eq

Volume 31, número 4, 2006

\section{Sensitive spectrophotometric assessment of carbofuran using dapsone as a new chromogenic reagent in formulations and environmental samples}

\author{
P. Nagaraja ${ }^{I^{*}}$ and B. L. Bhaskara \\ ${ }^{1}$ Department of Chemistry, University of Mysore, Manasagangotri, Mysore - 570 006, India, \\ *Autor for correspondence; e-mail: drpn58@yahoo.co.in
}

\begin{abstract}
A simple, sensitive and selective spectrophotometric method for the assessment of carbofuran in various formulations and in environmental water samples is described. The method is based on the coupling of hydrolyzed carbofuran with diazotized dapsone in alkaline medium at $0-4^{\circ} \mathrm{C}$ which gives orange red colored product having the absorption maximum at $480 \mathrm{~nm}$. The product is stable for $48 \mathrm{~h}$. Beer's law is obeyed in the concentration range of $0.1-4.0 \mu \mathrm{g} \mathrm{ml}^{-1}$. The molar absorptivity and Sandell's Sensitivity are $5.0 \times 10^{4} \mathrm{~L} \mathrm{~mol}-1 \mathrm{~cm}^{-1}$ and $4.4 \mathrm{ng} \mathrm{cm}^{-2}$ respectively. The method is highly reproducible and is confirmed by RSD values $(1.144 \%)$. From the recovery studies it is found that this method is accurate and it can be successfully employed for the determination of carbofuran.
\end{abstract}

Keywords: carbofuran; dapsone; spectrophotometry; assessment; formulations; environmental.

\section{Introduction}

Carbofuran (2, 3-dihydro-2, 2-dimethyl-7benzofuranol N-methylcarbamate), an anticholinesterase carbamate, is commonly used as an insecticide, nematicide, and acaricide in agricultural practice throughout the world [1]. It is highly toxic by inhalation and ingestion and moderately toxic by dermal absorption [2]. Risks from exposure to carbofuran are especially high for persons with asthma, diabetes, cardiovascular disease, mechanical obstruction of the gastrointestinal or urogenital tracts [3]. It has also a high potential for groundwater contamination [4]. As a result of its widespread use, carbofuran has been detected in ground, surface, rain waters, in soils, air, foods and wildlife [5, 6]. The formulated granules lead to bird-kill incidents [7]. By considering all these serious impacts on ecosystem it is inevitable to develop a sensitive and cost effective method for the assessment of carbofuran.
Comprehensive literature survey revels a number of methods for the analysis of carbofuran, which includes LC-MS [8-10], GC- MS [11,12], GC [13-16], GLC [17-21], HPLC [22-24], flow injection spectrophotometric [25] and spectrophotometric techniques [26-41]. Some of these reported methods need costly instruments, laborious procedure and less sensitive, these facts promoted us to develop sensitive and cost effective method.

The survey of literature reveals that there is little spectrophotometric method available for determination of carbofuran. Detection limit of few methods were $0.150 \mu \mathrm{g} / \mathrm{mL}$ [25], $0.250 \mu \mathrm{g} / \mathrm{mL}$ [26], $0.300 \mu \mathrm{g} / \mathrm{mL}$ [28], $0.804 \mu \mathrm{g} / \mathrm{mL}$ [40], 0.062 $\mu \mathrm{g} / \mathrm{mL}$ [41], found to be more when compare to proposed having detection limit $0.040 \mu \mathrm{g} / \mathrm{mL}$. The proposed method is based on the coupling of hydrolyzed carbofuran with diazotized dapsone in alkaline medium giving orange red product and intensity is measured at $480 \mathrm{~nm}$. This method can 
be effectively used as an alternative tool for the assessment of carbofuran in both environmental samples and commercial formulations.

\section{Experimental details}

Systronics spectrophotometer - 106 Model with $10 \mathrm{~mm}$ matched quartz cells was used throughout the spectral measurements.

\section{Reagents}

Carbofuran (99.9\% purity) was supplied by Rallis India Ltd. Bangalore, India. 4-4I- diaminodiphenyl sulfone (dapsone) was obtained from Merck (Germany), Sodium nitrite (BDH), Sodium hydroxide (AR), Sulphamic acid, (BDH) were used. All other chemicals used were analytical reagent grade. Double distilled water was used to prepare all solutions and commercial formulations were purchased from local sources and environmental samples were collected from nearby sources.

\section{Sample preparation}

A Stock solution of Carbofuran $(500 \mu \mathrm{g}$ $\mathrm{mL}^{-1}$ ) was prepared by dissolving $50 \mathrm{mg}$ of pure sample in methanol followed by $5 \mathrm{~mL}$ of $2 \mathrm{~mol} \mathrm{~L}^{-1}$ of methanolic sodium hydroxide and after $5 \mathrm{~min}$ the solution was made up to the volume in a $100 \mathrm{~mL}$ calibrated flask with methanol. Working standards were prepared by suitable dilution. A solution $0.2 \%$ $(\mathrm{m} / \mathrm{v})$ dapsone was prepared by dissolving $0.2 \mathrm{~g}$ of dapsone in $5 \mathrm{~mL}$ of $1 \mathrm{~mol} \mathrm{~L}^{-1}$ hydrochloric acid and then diluted to $100 \mathrm{~mL}$ with water. Aqueous solutions of $0.5 \%(\mathrm{~m} / \mathrm{v})$ Sodium nitrate, $2 \%(\mathrm{~m} / \mathrm{v})$ Sulphamic acid solution, and $2 \mathrm{~mol} \mathrm{~L}-1$ methanolic sodium hydroxide solutions were prepared.

\section{Sample Preparations.-}

Furadan 3G working solution (Furadan 3G granular, Manufactured and Marketed by Rallis India Ltd. Bangalore, India) was prepared by transferring $333.30 \mathrm{mg}$ in $100 \mathrm{~mL}$ volumetric flask, then dissolved and diluted to the mark with methanol to get $100 \mu \mathrm{g} \mathrm{mL}^{-1}$. Suitable aliquots were analyzed for the estimation of carbofuran using the proposed method.

Carbofuran 10G working solution (Marketed by AIMCO Pesticides Ltd. Mumbai, India) was prepared by transferring $100.0 \mathrm{mg}$ in $100 \mathrm{~mL}$ volumetric flask, then dissolved and diluted to the mark with methanol to get $100 \mu \mathrm{g} \mathrm{mL}-1$. Suitable aliquots were analyzed for the estimation of carbofuran using the proposed method.

Tap water, pond water and river water were collected (100 mL each) from Manasagangotri, Kukkarahalli and Kaveri River respectively. These samples were spiked by adding known amounts of carbofuran concentration which lies within the Beer's law range (0.1- $\left.4.0 \mu \mathrm{g} \mathrm{mL}^{-1}\right)$. Using the proposed method, recovery studies was performed.

\section{Recommended procedure:}

$1.0 \mathrm{~mL}$ of $0.2 \%(\mathrm{~m} / \mathrm{v})$ dapsone solution was transferred into each of series of $10 \mathrm{~mL}$ calibrated flasks. $1.0 \mathrm{~mL}$ of $1.0 \%(\mathrm{~m} / \mathrm{v})$ aqueous solution of sodium nitrate was added and cooled in ice water bath for $3 \mathrm{~min}$ to attain the temperature around $5^{\circ}$ C. A $2.0 \mathrm{~mL}$ of $2.0 \%(\mathrm{~m} / \mathrm{v})$ aqueous solution of sulphamic acid was added and reaction mixture was allowed to stand for $2 \mathrm{~min}$ with occasional shaking. Aliquot of standard solution of carbofuran $(1.0-40 \mu \mathrm{g})$ was added to the above and resulting solution was made up to the mark with $2 \mathrm{~mol} \mathrm{~L}^{-1}$ methanolic sodium hydroxide and mixed thoroughly. The absorbance of resulting orange red colored solution was measured at 480 $\mathrm{nm}$ against the corresponding reagent blank, which has negligible absorption at this wavelength and calibration graph was constructed.

\section{Results and Discussions}

\section{Spectral characteristics}

The proposed method involves the coupling reaction of diazotized dapsone with the hydrolyzed product of carbofuran in sodium hydroxide medium to give orange red colored product having maximum absorption at $\lambda_{\text {max }} 480 \mathrm{~nm}$. This wavelength was used for all measurements. The Beer's Law range and molar absorptivity were $0.1-4.0 \mu \mathrm{g} \mathrm{mL}^{-1}$, $5.0 \mathrm{X} 10^{4} \mathrm{~L} \mathrm{~mol}^{-1} \mathrm{~cm}^{-1}$ respectively. The Sandell's sensitivity of the method was $4.4 \mathrm{ng} \mathrm{cm}^{-2}$. The absorption spectrum of the reaction product formed is shown in the Fig. 1. The corresponding reagent blank has practically negligible absorbance at this wavelength. 


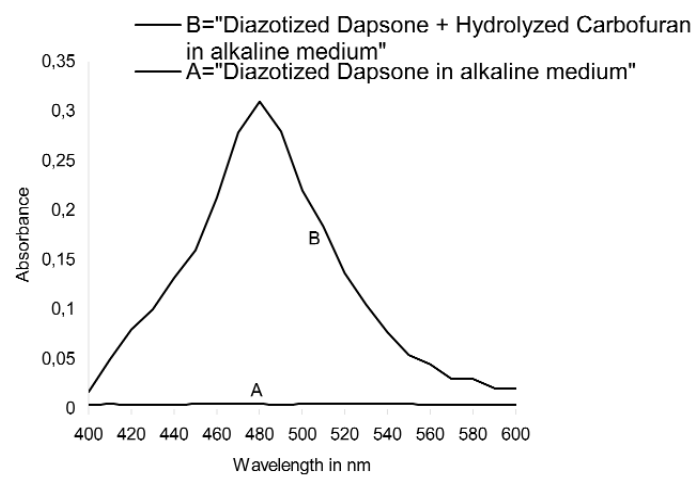

Figure1. Absorption Spectra of the both Reagent blank and Reaction Product of hydrolyzed Carbofuran and Diazotized Dapsone in the presence of alkaline medium. Final Concentration of Hydrolyzed carbofuran $=2.0 \mu \mathrm{g} \mathrm{mL}^{-1}$.

\section{Optimization of the reagent concentration}

Various concentration and volume ranges for all the reagents were studied in detail. However, the following are the optimum concentration and volume ranges. For the diazotization coupling reaction, it was found that $1.0 \%(\mathrm{~m} / \mathrm{v})$ sodium nitrate solution in the range of $1.0-3.0 \mathrm{~mL}, 2.0 \%(\mathrm{~m} / \mathrm{v})$ sulphamic acid solution in the range of $1.0-4.0 \mathrm{~mL}$ were optimum to achieve maximum color intensity. Hence, $1.0 \mathrm{~mL}$ of sodium nitrate, $2.0 \mathrm{~mL}$ of sulphamic acid and $1.0 \mathrm{~mL}$ of dapsone were selected for diazotization. The excess of nitrate added during diazotization reaction was removed by the addition of sulphamic acid. An excess of sulphamic acid was found to have no effect on color intensity. Dilution of the coupled product obtained by the interaction of hydrolyzed product of carbofuran and diazotized dapsone was studied water, ethanol, hydrochloric acid, sodium hydroxide and sulphuric acid. Results showed that $2 \mathrm{~mol} \mathrm{~L}^{-1}$ methanolic sodium hydroxide was found to give maximum color intensity and stability of resulting product.

\section{Quantification}

Adherence to the Beer's law by the colored product of diazotized dapsone with hydrolyzed carbofuran was determined by measuring the absorbance at $480 \mathrm{~nm}$ for a set of solutions containing varying amounts of analyte and specified amounts of reagents against colorless reagent blank. Beer's law was obeyed over the hydrolyzed carbofuran range of $0.1-4.0 \mu \mathrm{g} \mathrm{mL}-1$. Limit of quantification (LOQ) is determined by taking the ratio of standard deviation $(\sigma)$ of the blank with respect to water and the slope of the calibration curve (a) multiplied by a factor 10. LOQ is approximately 3.3 times the limit of detection (LOD). Naturally, the LOQ slightly crosses the lower limit of the Beer's law range. But LOD is well below the lower limit of the Beer's law range. The upper limit of the Beer-Lambert range is determined by a plot of absorbance against concentration at the value of $\lambda_{\text {max }}$. Beyond this limit, the correlation results were really affected. Hence, the measurements were excluded above these limits to keep the relationship linear.

\section{Method Validation}

The accuracy of the method was established by Recovery studies of hydrolyzed carbofuran at three levels (within the Calibrated graph). The precision was ascertained by calculating the relative standard deviation (RSD) of seven replicate determinations at three levels. The RSD (\%) and range of error (\%) and values were 1.144 and 1.143 respectively. Which were less than $2 \%$ are indicative of good accuracy and precision of the method. The LOD and LOQ of the method were found to be 0.04 and $0.13 \mu \mathrm{g} \mathrm{mL}-1$ respectively. From the regression equation it was observed that correlation coefficient and slope of the curve were 0.9978 and 0.1696 respectively.

\section{Reaction sequence}

Carbofuran when dissolved in methanolic sodium hydroxide undergoes hydrolysis to form carbofuran phenol which couples with diazonium cation produced by the diazotization of dapsone to produce the orange red colored product. For the diazotization process, it is expected that the two $\mathrm{NH}_{2}$ groups in dapsone will be readily diazotized and each diazonium group will then react with two molecule of carbofuran phenol. When the same reaction was carried out with carbofuran dissolved in ethanol or methanol instead of sodium hydroxide does color, this clearly indicates that it is the hydrolysis product of carbofuran which is coupling with diazotized dapsone. The reaction mechanism for the formation of the product is shown in scheme 1 . 

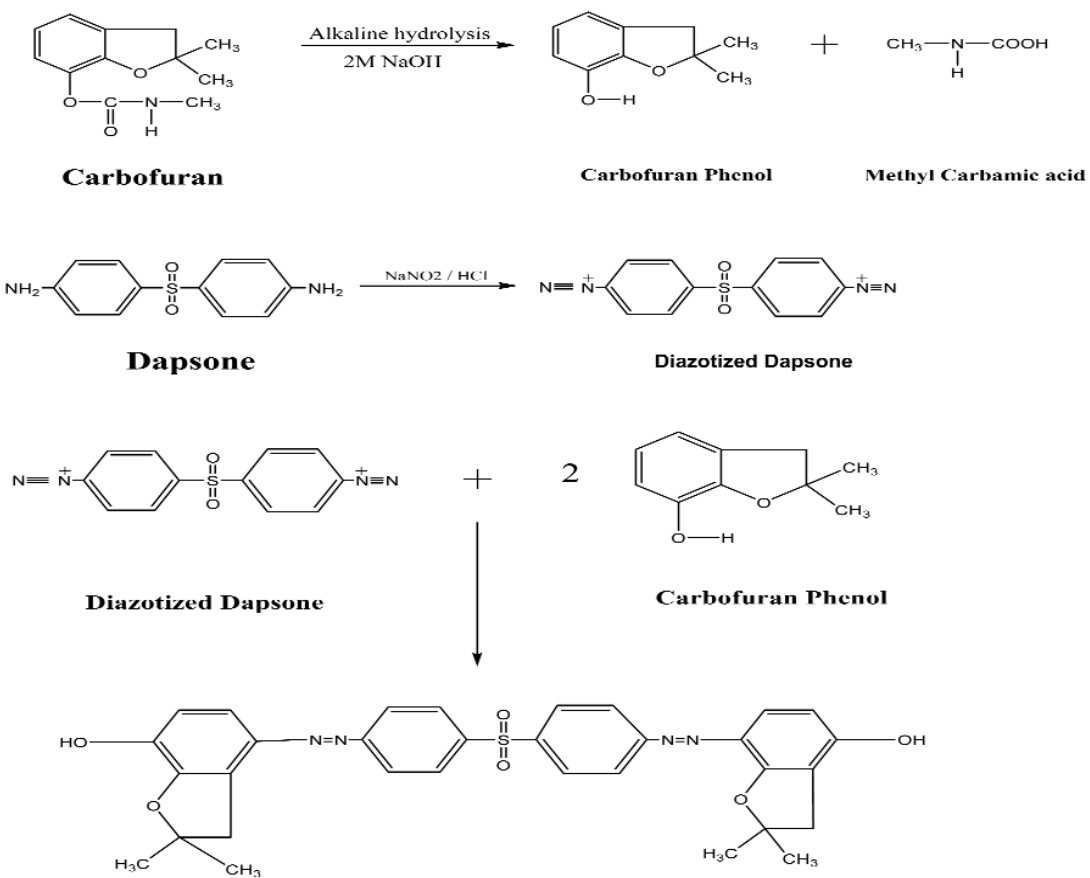

Orange red colored azo product $\left(\lambda_{\max } 480 \mathrm{~nm}\right)$

Scheme1. Proposed Reaction Path of Hydrolyzed Carbofuran with Diazotized Dapsone in the Presence of Alkaline medium.

\section{Effect of temperature and color stability}

Under the optimized condition, the orange red colored product was found to be stable for 48 h. Reproducible results were produced in the temperature range of $20-55^{\circ} \mathrm{C}$. An increase in temperature above $55^{\circ} \mathrm{C}$ decreased in the absorbance readings indicating the decomposition of the product. However, a temperature of $30^{\circ} \mathrm{C}$ is recommended for the absorbance measurements.

\section{Effect of Foreign Species}

The suitability of the method for application to water samples and other environmental samples were studied by taking various cations, anions and other pesticide species in solutions containing $2.0 \mu \mathrm{g} \mathrm{mL}^{-1}$ carbofuran. The results are given in the Table 3. The other pesticides such as parathion ethyl, Malathion, fenitrothion, 2, 4-D, parathion methyl, did not interfere ser-

Table 1. Elemental analysis data of $\mathrm{Co}(\mathrm{II}), \mathrm{Ni}(\mathrm{II})$ and $\mathrm{Cu}(\mathrm{II})$ 3-chloro-2-nitrobenzoates

\begin{tabular}{ccccccccccc}
\hline \multirow{2}{*}{ Complex } & \multicolumn{2}{c}{$\mathrm{C} / \%$} & $\mathrm{H} / \%$ & \multicolumn{2}{c}{$\mathrm{Cl} / \%$} & $\mathrm{~N} / \%$ & $\mathrm{M} / \%$ \\
\cline { 2 - 10 } $\begin{array}{c}\mathrm{L}^{-} \\
=\mathrm{C}_{7} \mathrm{H}_{3} \mathrm{O}_{4} \mathrm{NCl}\end{array}$ & calcd. found calcd. found calcd. found & calcd. found calcd. found \\
\hline $\mathrm{CoL}_{2} \cdot 2 \mathrm{H}_{2} \mathrm{O}$ & 33.87 & 33.67 & 2.01 & 2.00 & 14.31 & 14.30 & 5.64 & 5.62 & 11.88 & 11.80 \\
$\mathrm{NiL}_{2} \cdot 2 \mathrm{H}_{2} \mathrm{O}$ & 33.87 & 33.58 & 2.01 & 2.01 & 14.37 & 14.35 & 5.64 & 5.63 & 11.87 & 11.85 \\
$\mathrm{Cu}_{2} \mathrm{~L}_{4} \cdot 2 \mathrm{H}_{2} \mathrm{O}$ & 33.60 & 33.70 & 1.60 & 1.58 & 14.20 & 14.21 & 5.60 & 5.60 & 12.68 & 12.64 \\
\hline
\end{tabular}


iously. The tolerance limits given in Table 1 are the concentrations of diverse species that cause \pm $2 \%$ error in the determination of carbofuran by this method. The results also showed that a large number of metallic and non-metallic ions did not interfere.

\section{Applications}

Determination of carbofuran in Commercial Formulations. -

The method was applied to determine carbofuran in different carbofuran formulations. Here, two different commercial formulations [Furadan 3G (granular) and 10G (granular)] were prepared by appropriate dilution with methanol (within the Beer's Law range 0.1- $4.0 \mu \mathrm{g} \mathrm{mL}^{-1}$ ) and analyzed by the recommended procedure. The results are represented in Table 2. Statistical data showed that this method can be effectively emplo- yed for the determination of carbofuran in various environmental and commercial formulations.

\section{Recovery of the carbofuran residues from spiked} water samples.

Water samples $(100 \mathrm{~mL})$ were spiked with known amount of carbofuran $\left(0.1-4.0 \mu \mathrm{g} \mathrm{mL}^{-1}\right)$ in methanol. The mixture was transferred into a separating funnel and insecticide was extracted using approximately $15 \mathrm{~mL}$ of Chloroform in each occasion till complete extraction. The combined extracts were washed with $2 \mathrm{~mL}$ of $0.1 \mathrm{~mol} \mathrm{~L}^{-1}$ potassium carbonate to break any emulsion formed during the extraction. The extracted insecticide was dried over anhydrous sodium sulphate. Chloroform was evaporated on a water bath and residue was dissolved in methanol. The amount of carbofuran was determined using the proposed procedure and data are shown in table 3 .

Table 2. Wavenumbers $\left(\mathrm{cm}^{-1}\right)$ of $\mathrm{COO}^{-}$bands in 3-chloro-2-nitrobenzoates of $\mathrm{Co}(\mathrm{II}), \mathrm{Ni}(\mathrm{II})$, $\mathrm{Cu}(\mathrm{II})$ and $\mathrm{Na}$ and of the $\mathrm{COOH}$

\begin{tabular}{ccccccc}
\hline $\begin{array}{c}\text { Complex } \\
\mathrm{L}^{-} \\
\mathrm{C}_{7} \mathrm{H}_{3} \mathrm{O}_{4} \mathrm{NCl}\end{array}$ & $v_{\mathrm{C}=\mathrm{O}}$ & $v_{\text {asOCO }}$ & $v_{\mathrm{sOCO}}$ & $\Delta v_{\mathrm{OCO}}$ & $v_{\mathrm{C}-\mathrm{Cl}}$ & $v_{\mathrm{M}-\mathrm{O}}$ \\
\hline $\mathrm{CoL}_{2} \cdot 2 \mathrm{H}_{2} \mathrm{O}$ & - & 1590 & 1400 & 190 & 740 & 500 \\
$\mathrm{NiL}_{2} \cdot 2 \mathrm{H}_{2} \mathrm{O}$ & - & 1590 & 1410 & 180 & 740 & 480 \\
$\mathrm{Cu}_{2} \mathrm{~L}_{4} \cdot 2 \mathrm{H}_{2} \mathrm{O}$ & & 1610 & 1410 & 200 & 750 & 530 \\
$\mathrm{HL}$ & 1710 & - & - & - & - & - \\
$\mathrm{NaL}$ & - & 1625 & 1400 & 225 & 760 & 440 \\
\hline
\end{tabular}

Table 3. Average Recovery of Carbofuran from Spiked Water Samples using Proposed Method

\begin{tabular}{|c|c|c|c|c|c|c|}
\hline & Tap Water ${ }^{b}$ & & Pond & ater $^{\mathrm{c}}$ & & River Water ${ }^{\mathrm{d}}$ \\
\hline $\begin{array}{l}\text { Carbofuran } \\
\text { Fortified in } \\
\mu \mathrm{g} \mathrm{mL}^{-1}\end{array}$ & $\begin{array}{l}\text { Carbofuran } \\
\text { Found } \\
\text { in } \mu \mathrm{g} \mathrm{mL}^{-1}\end{array}$ & $\begin{array}{l}\text { Recovery } \\
\% \text { [RSD] }^{\mathrm{a}}\end{array}$ & $\begin{array}{l}\text { Carbofuran } \\
\text { Found } \\
\text { in } \mu \mathrm{g} \mathrm{mL}^{-1}\end{array}$ & $\begin{array}{l}\text { Recovery } \\
\%[\mathrm{RSD}]^{\mathrm{a}}\end{array}$ & $\begin{array}{l}\text { Carbofuran } \\
\text { Found } \\
\text { in } \mu \mathrm{g} \mathrm{mL}^{-1}\end{array}$ & $\begin{array}{c}\text { Recovery \% } \\
\text { [RSD] }^{\mathrm{a}}\end{array}$ \\
\hline 0.75 & 0.71 & $95.26 \pm 0.06$ & 0.70 & $96.99 \pm 0.89$ & 0.72 & $95.69 \pm 1.44$ \\
\hline 1.50 & 1.44 & $96.01 \pm 0.80$ & 1.43 & $95.22 \pm 0.55$ & 1.45 & $96.88 \pm 1.09$ \\
\hline 2.25 & 2.16 & $95.89 \pm 0.1$ & 2.12 & $94.15 \pm 0.67$ & 2.16 & $96.19 \pm 0.78$ \\
\hline 3.0 & 2.93 & $97.50 \pm 0.89$ & 2.80 & $93.38 \pm 1.09$ & 2.91 & $97.00 \pm 0.69$ \\
\hline 3.5 & 3.38 & $96.68 \pm 0.72$ & 3.33 & $95.21 \pm 1.11$ & 3.38 & $96.65 \pm 0.28$ \\
\hline 4.0 & 3.88 & $97.09 \pm 1.04$ & 3.75 & $93.85 \pm 1.18$ & 3.80 & $95.01 \pm 1.20$ \\
\hline
\end{tabular}

${ }^{a}$ = Average values of seven determinations, Water samples $\left(100 \mathrm{~mL}\right.$ each) were collected from Manasagangotri ${ }^{b}$,

University of Mysore Kukkarahalli ${ }^{\mathrm{c}}$, Mysore District, Karnataka, India. Kaveri River ${ }^{\mathrm{d}}$, Mandya District, Karnataka, India 


\section{Conclusions}

The proposed spectrophotometric method is simple to perform, cost effective. The sensitivity, simplicity, temperature independence and stability of the colored product are the advantages of this method. The diazotizing reagent used here is colorless, highly water soluble and cheaper when compared to the other reagents used in reported methods. This method can be used to detect $0.040 \mu \mathrm{g} \mathrm{mL}^{-1}$ and quantitatively detect $0.130 \mu \mathrm{g} \mathrm{mL}^{-1}$ of carbofuran and does not involve extraction step and the use of carcinogenic solvents. The proposed method does not entail any stringent experimental variables which affect the reliability of the results. From the recovery studies, it reveals that this method can serve as an alternative method for determining carbofuran residues in various environmental samples.

\section{Acknowledgements}

One of the authors (B.L.B.) thanks the University of Mysore for providing the laboratory facilities.

Received 11 September 2006

Accepted 22 November 2006

\section{References}

[1] R.C. Gupta, Carbofuran toxicity. J Toxicol. Environ. Health 43 (1994) 383.

[2] R. L. Baron, Carbamate insecticides, In Handbook of Pesticide Toxicology, Hayes, W. J. Jr. , E. R Laws Jr, Eds, Academic Press, New York, $3,1991$.

[3] U.S. Department of Agriculture, Soil Conservation Service, SCS/ARS/CES Pesticide Properties Database: Version 2.0 (Summary). USDA - Soil Conservation Service, Syracuse, New York, (1990).

[4] P. H. Howard, Handbook of Environmental Fate and Exposure Data for Organic Chemicals: Pesticides. Lewis Publishers, Chelsea, MI, 3 ,1991.

[5] R.P. Richards, L.W. Kramer, D.B. Baker, K.A. Krieger, Nature 327 (1987) 129.

[6] D.T. Waite, R Grover, N.D. Wescott, H. Sommerstand, L. Karr, Environ. Toxicol. Chem. 11 (1992) 741.

[7] N. W. Erwin, Journal of Pesticide Reform 11(4) (1991) 15. [8] C. H. Soler, F. Brett, J. Ambrose, J. K. Manes, Y.J. Pico, Anal. Chim. Acta 571(1) (2006) 1.

[9] Pang, Guo-Fang Liu, Yong-Ming Fan, Chun-Lin Zhang, JinJie Cao,Yan-Zhong Li, Xue-Min Li, Zeng-Yin Wu, Yan-Ping
Guo, Tong-Tong, Anal. Bioanal. Chem. 384(6), (2006), 1366.

[10] F. Hernandez, O. J Pozo, J. V. Sancho, L. Bijlsma, M. Barreda, E. Pitarch, Spain Journal of Chromatography A 1109(2) (2006) 242.

[11] T. Kawamoto, N. Makihata, Analytical Sciences 19 (2003) 1605.

[12] E. S. Petropoulou, E. T. Gikas, P. S. Anthony, A, Journal of Chromatography A 1115 (1-2) (2006) 271.

[13] L. Wong, Fisher F M, J. Agric Food Chem 23 (1975) 315.

[14] R .F. Cook, R. P. Stanovick, C. C. Cassil, J. Agric Food Chem. 17 (1969) 277.

[15] L. I. Bulter, L.M.McDonough, J. Agric. Food Chem. 54 (1971) 1357.

[16] C. H .Van Middelem, H. A. Moye, M. J .Janes, J. Agric Food Chem. 19 (1971) 459.

[17] O. Agrawal, V. K. Gupta, J. Microchemical 62(1) (1999) 147.

[18] M.C. Bowman, M. Beroza, J. Assoc. Off Anal Chem. 50 (1967) 926.

[19] L. I. Butler, L. M. McDonough, J. Agric. Food Chem. 16 (1968) 403.

[20] C. C. Cassil, R. P. Stanovick, C. C. Cassil, Res. Rev. 26(1969) 63.

[21] J. N Seiber, J. Agric Food Chem. 20 (1972) 443.

[22] I. H. Williams, M. J. Brown, J. Agric Food Chem. 21 (1973) 399.

[23] R. W. Frei, J. F. Lawrence, J. Hope, R. M. Cassidy, J. Chromatogr. Sci. 12 (1974) 40.

[24] J. F. Lawrence, R. Leduc, J. Agric Food Chem. 25 (1977) 1362.

[25] Z. Renato, D.M. Rogério, P. V. Cristiane , Pest Mangement Science 56 (9) (2000) 804.

[26] J. R. Rangaswamy, Y. N. Vijayashankar, S. R Prabhakar, J. Assoc. Anal. Chem. 59 (1976) 1276.

[27] S. K. Handa, A. K. Dikshit, J. Assoc. Anal. Chem. 61 (1978) 1513.

[28] K. M. Appaiah, R. Ramakrishna, K. R. Subba Rao, K. V. Nagaraja, O.P. Kapur, J.Food Sci. Technol. 19 (1982) 211.

[29] V. Harikrishna, B. Prasad, N. V. S. Naidu, J. Indian Council of Chemists 2 (2003) 20.

[30] C. V. Rajeswari, P. R. Naidu, J. Food Sci. Technol. 23 (1986) 101.

[31] R. Kumar, C. B. Sharma, Anal. Lett. 20 (1987) 777.

[32] D. V. Naidu, P. R. Naidu, Proc. Indian Natl.Sci.Acad. 56 (1990) 203.

[33] A. Salvador, Z. A. Debenzo, M. Dela Guardia, J. Micro Chem. 42(1990) 187.

[34] S. K. Handa, J. Assoc Off Anal. Chem. 63(1980) 200.

[35] C. V. Rajeswari, A. V. Naidu, P. R .Naidu, Curr. Sci. 53 (15) (1984) 800.

[36] Alvarez-Rodriguez A, Monferrer-Pns Li, Esteve-Romero J, Garcia-M. C. Alverez-Coque, G.Ramis-Ramus, Analyst 122 (1997) 459.

[37] M. S. Mithyantha, N. G .Perur, Curr. Sci. 43 (1974) 18.

[38] R. Zenalla, R. M. Dalloago, E. M .M. Flores, A.F. Maritins, Analytical Letters 32(3) (1999) 593.

[39] R. Kesart, J. V. Das, V. K. Gupta, J. Ind. Chem. Soc. 75(3) (1998) 181

[40] M.R. Jan, J. Shah , H. Khan , Chemosphere 52(9) (2003) 1623.

[41] O. Bhargavi, K. Kiran, K. Suvardhan, D. Rekha, K. Janardhanam, P. Chiranjeevi, E-Journal of Chemistry 3(11) (2006) 68. 